\title{
Conserving on the edge: genetic variation and structure in northern populations of the endangered plant Dracocephalum ruyschiana L. (Lamiaceae)
}

\author{
Magni Olsen Kyrkjeeide ${ }^{1}\left[\right.$ ( $\cdot$ Kristine Bakke Westergaard $^{1} \cdot$ Oddmund Kleven $^{1} \cdot$ Marianne Evju $^{2} \cdot$ Anders Endrestøl $^{2}$. \\ Marie Kristine Brandrud ${ }^{2}$. Odd Stabbetorp ${ }^{2}$
}

Received: 3 April 2019 / Accepted: 14 May 2020 / Published online: 20 May 2020

(c) The Author(s) 2020

\begin{abstract}
Loss of biodiversity is accelerating, including the loss of genetic diversity. Conservation of small, isolated populations may be important, as they can provide valuable contributions to overall genetic variation and long-term viability of species. Furthermore, such populations may play an essential role in adaptation to new environments following changes in e.g. land-use and climate. Dracocephalum ruyschiana is a threatened plant species throughout its European distribution, but $25 \%$ of the European populations are situated within Norway. Therefore, the species has its own action plan in Norway, which includes demographic monitoring. However, this monitoring does not cover genetic variation nor is the selection of monitored populations based on genetic differentiation, therefore this fundamental level of biodiversity is overlooked. We analyzed 43 sites using 96 SNPs developed for D. ruyschiana, to investigate whether the monitored populations cover the genetic variation and differentiation found within the Norwegian distribution. The results show structuring and differentiation between populations and indicate that there are at least four distinct genetic groups, of which only two are covered extensively by current demographic monitoring. We suggest that two sites representing the two other genetic groups should be included in the national monitoring program to better conserve the genetic variation found in the Norwegian population of $D$. ruyschiana. Overall, our results highlight the importance of an integrated, interdisciplinary framework to better monitor and conserve biodiversity at several levels.
\end{abstract}

Keywords Conservation genetics $\cdot$ Genetic monitoring $\cdot$ Genetic structure $\cdot$ Management $\cdot$ Norway $\cdot$ Peripheral populations

\section{Introduction}

The loss of biodiversity is accelerating with negative consequences for populations, species, communities and ecosystems (Hughes et al. 2008; Ceballos et al. 2015). The main threat to biodiversity loss is land-use change (IPBES 2019), which causes population fragmentation that may lead to loss

Electronic supplementary material The online version of this article (https://doi.org/10.1007/s10592-020-01281-7) contains supplementary material, which is available to authorized users.

Magni Olsen Kyrkjeeide

magni.kyrkjeeide@nina.no

1 Norwegian Institute for Nature Research (NINA), P.O. Box 5685, Torgarden, 7485 Trondheim, Norway

2 Norwegian Institute for Nature Research (NINA), Gaustadalléen 21, 0349 Oslo, Norway of genetic diversity (Aguilar et al. 2008). Genetic variation is the smallest unit of biodiversity, and thus crucial for conserving biodiversity at higher levels, such as species and ecosystems (Bruford et al. 2017). Conserving genetic diversity provides genotypes for selection in a changing environment (Barrett and Schluter 2008), contributes to faster recovery of populations after disturbance (Reusch et al. 2005), and increases the stability of ecosystem processes (Crutsinger et al. 2006; Des Roches et al. 2018).

An important international political document for halting biodiversity loss is the United Nations' Convention on Biological Diversity (CBD; www.cbd.int), which also gives an explicit goal to protect genetic diversity. The fundamental idea is that conservation should aim to conserve evolutionary processes, adaptive potential, and not just current species (Bowen 1999). However, very limited action has yet been taken on a global scale to fulfil this goal (Laikre 2010; 

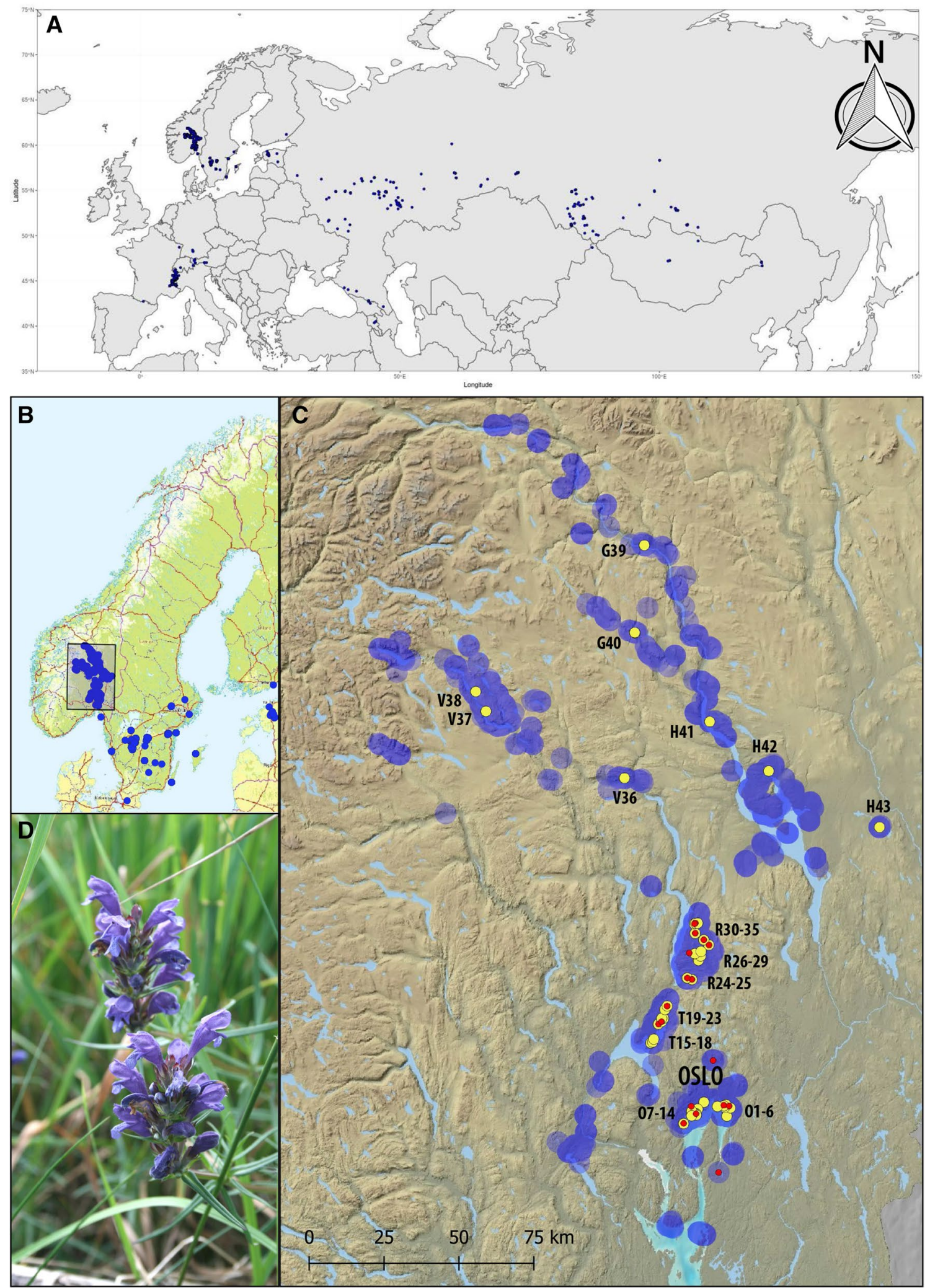

Laikre et al. 2010). Furthermore, the IUCN Red List does not consider genetic variation (Rivers et al. 2014).
Populations of threatened species are typically small and isolated. Such populations may exhibit lower genetic variation than larger populations, potentially reducing their 
4Fig. 1 a The global distribution of Dracocephalum ruyschiana based on data from GBIF Secretariat (2017, see Lazarević et al. 2009 for a more detailed map). b The distribution of D. ryusciana in Fennoscandia based on data collected after 1975 (GBIF Secretariat 2017). c Norwegian distribution of $D$. ruyschiana (blue dots, data from Norwegian Biodiversity Information Centre, artsdatabanken.no), the collected sites for this study (yellow dots) and sites that are currently included in demographic monitoring (red dots). The site ID indicated in the map follows Table 1 and the assigned geographical regions are indicated by the letter in the ID (O-Oslofjorden, T-Tyrifjorden, R-Randsfjorden, V-Valdres, G-Gudbrandsdalen, H-Hedmark). The Norwegian populations of $D$. ruyschiana are situated in the southeastern parts of Norway. D: Flowering stand of D. ruyschiana (photo: Anders Endrestøl)

abilities to adapt to changing environmental conditions (Keller and Waller 2002; Barrett and Schluter 2008). Moreover, small populations are more prone to genetic drift and inbreeding than larger populations, further lowering their genetic diversity (for example, Wagner et al. 2012). Regardless of levels of genetic variation, populations at the distribution margin may play an important role in the range shift of species following climate change (Razgour et al. 2013). Furthermore, such populations can also hold unique ecological and genetic variation (Osborne et al. 2012) and potentially enhance within-species genetic diversity (García-Ramos and Kirkpatrick 1997). Thus, conserving these populations may be especially important, particularly if the species is threatened across its entire distribution.

To conserve genetic diversity and guide practical conservation strategies, it is crucial to identify population-genetic structuring, such as genetic distinctiveness and diversity, and ideally to couple this information with knowledge on geographical barriers and divergent local ecological adaptation. In Norway, only a few rare and endangered plant species have been investigated genetically with the intention to guide conservation plans (Westergaard et al. 2011a, b; Birkeland et al. 2017; Westergaard et al. 2019).

Here we use the vascular plant 'northern dragonhead' Dracocephalum ruyschiana $\mathrm{L}$. as a case to investigate how analyses of genetic variation can be used to guide decision makers and management when conserving biodiversity nationally. The populations of $D$. ruyschiana are rapidly declining in Europe: the species is listed under Appendix 1 of the Bern Convention (http://conventions.coe.int/Treaty/ FR/Treaties/Html/104-2.htm) as well as on many national and regional Red Lists (e.g. Gärdenfors 2005; Király 2007; Witkowski et al. 2003), including the Norwegian Red List, in which it is listed as vulnerable (VU) (Henriksen and Hilmo 2015). Habitat loss due to urbanization or decreasing management of agricultural land, is considered the main threat to the species in Norway (Solstad et al. 2015), as well as in several European countries (Käsermann and Moser 1999; Lazarevic et al. 2009). Despite the documented decline of D. ruyschiana, knowledge of genetic variability, structure and evolutionary history of this species is still lacking for Norwegian and global populations.

Dracocephalum ruyschiana (Lamiaceae, $2 \mathrm{n}=2 \mathrm{x}=14$ ) is a long-lived, insect-pollinated herb with a continental, fragmented distribution in Eurasia (Lid and Lid 2005; Lazarevic et al. 2009). It is a typical steppe plant, and grows on exposed, well-drained, shallow calcareous soils in dry meadows and rocky outcrops (Lid and Lid 2005; Lazarevic et al. 2009). In Europe (excluding Russia), more than 25\% of the remaining populations are found in Norway (Norwegian Directorate for Nature Management 2010). The species reaches its European northwestern limit in Norway, where it has a southeastern distribution through the country (Fægri and Danielsen 1996, Lazarevic et al. 2009). The Norwegian habitats of D. ruyschiana include dry calcareous meadows, rocky outcrops along roads, and extensively managed agricultural lands (Norwegian Directorate for Nature Management 2010). Mature plants have several stems normally approximately $30 \mathrm{~cm}$ long, arising from a short, branched rhizome (Lid and Lid 2005). The flowering period is typically in the middle of June, and the flowers are blue, $2-2.5 \mathrm{~cm}$ long, and gathered in a spike-like inflorescence with 50-60 flowers (Fig. 1d). The flowers are mainly pollinated by long-tongued insects such as bumblebees Bombus ssp. (Milberg and Bertilsson 1997). The fruits are typical for the family Lamiaceae, resulting in four dry one-seeded nutlets, without obvious adaptations for long-distance dispersal. The species is most likely self-compatible (Milberg and Bertilsson 1997), as self-incompatibility systems are not known from the Lamiaceae (Owens and Ubera-Jiménez 1992; Allen and Hiscock 2008).

In Norway, $D$. ruyschiana is one of only three vascular plants regulated to have priority for conservation (Lovdata 2011). As a large part of the European population is located in Norway, it is crucial to conserve the species nationally. Thus, an action plan for conservation has been prepared (Norwegian Directorate for Nature Management 2010) and a monitoring program for Norwegian populations of $D$. ruyschiana developed (Evju et al. 2016), aiming to collect data on population size and structure to inform managers on status and trends for the species at the national level. The monitoring protocol has so far been tested on 18 populations in and around the city of Oslo (Evju pers. comm.). The selection of populations was not based on genetic variation or structuring in the species, but on geographic clustering (regions). Furthermore, the action plan includes no actions to conserve genetic diversity.

Here we use single nucleotide polymorphisms (SNPs) developed for D. ruyschiana (Kleven et al. 2019) to investigate genetic diversity and structure within Norway. In particular, we aim at identifying genetic groups within its Norwegian distribution to evaluate whether established national monitoring sites sufficiently cover the observed 
genetic variation and structuring observed. Our results may help guide future practical conservation management of $D$. ruyschiana, and serve as an example of combining genetic analyses with traditional demographic monitoring of plant species.

\section{Methods}

\section{Specimen sampling, DNA extraction and SNP dataset}

With collection permits from local authorities (see Acknowledgements), leaf material of $D$. ruyschiana was sampled from 43 sites across the Norwegian distribution range (Table 1, Fig. 1), with relatively sparser coverage of the distribution margins. Samples were taken in 2012-2014, prior to the development and establishment of the monitoring program in 2016 and 2017, respectively, therefore there is not complete overlap between our sites and the monitored sites. Two different sampling schemes were used when collecting leaves. In the first scheme, ten $1 \mathrm{~m}^{2}$-plots were randomly placed across a site, after first identifying all flowering clusters of $D$. ruyschiana. Leaves were then sampled from the plant closest to the center of the plot. In total, 20 sites were sampled using this scheme, and later several of these sites were included in the monitoring initiated in 2017. For the second sampling scheme in the remaining 23 sites, plants were sampled randomly. Where possible, 10 individuals were sampled from each site, however, in sites with fewer than 10 clusters of individuals (likely belonging to the same clone), leaves from one plant representing each cluster were collected.

We delimited six regions based on geographic proximity and topographic barriers, and assigned all sampled sites to a region: Oslofjorden (14), Tyrifjorden (nine), Randsfjorden (12), Valdres (three) Gudbrandsdalen (three) and Hedmark (three).

Genomic DNA was extracted from the silica dried leaves using either the NucleoSpin Plant II extraction kit (Macherey-Nagel) or DNeasyPlant Mini Kit (Qiagen), following the manufacturer's protocols. The amount of extracted DNA was quantified on a Qubit 2.0 using the HS Assay kit (Thermo Fisher Scientific). All samples were genotyped at 96 presumably non-coding SNPs applying a SNP-typing assay recently developed specifically for the purpose of facilitating monitoring of the northern dragonhead (see Kleven et al. 2019 for details). Briefly, SNPs were genotyped on a 96.96 Dynamic Array using the Fluidigm EP1 instrument according to the manufacturer's protocol and scored using the Fluidigm SNP genotyping analysis software (https:// www.fluidigm.com/software). Deviation from Hardy-Weinberg equilibrium for each SNP in each population was estimated using Arlequin ver. 3.5.1.2 (Excoffier and Lischer 2010). As none of the 96 SNPs deviated significantly from Hardy-Weinberg equilibrium consistently across populations, we included all SNPs in the downstream analyses.

\section{Genetic diversity and structure}

Genetic diversities in each D. ruyschiana site were explored by calculating mean number of alleles $\left(N_{\mathrm{A}}\right)$, observed $\left(H_{\mathrm{O}}\right)$ and expected $\left(H_{\mathrm{E}}\right)$ heterozygosity, the inbreeding coefficient $(F)$ and percentage of heterozygous loci in GenAlEx 6.5 software (Peakall and Smouse 2006, 2012). Furthermore, structuring of genetic variation within and between sites, and between the six geographic regions was estimated in analyses of molecular variances (AMOVA), and population differentiation at the regional level was estimated using the $F_{\mathrm{ST}}$-value. We performed one more analyses in GenAlEx 6.5: the assignment test by using the "leave one out" option to explore the origin of individuals based on their genotypes. We also tested whether genetic distance was correlated with geographical distance, using the Mantel test (mantel.randtest) with 999 permutations with the R package ADE4 v1.713 (Dray and Dufour 2007) in R v.3.2.3 in RSTUDIO v. 1.0.44 (RStudio Team 2015).

Genetic structuring was explored using MULTISPATIPCA (Dray et al. 2008) performed with the R package ADE4 v1.7-13 (Dray and Dufour 2007) and SPDEP v1.1-2 (Bivand et al. 2008). This MULTISPATI-PCA is an extension of the principal component analysis that also takes the spatial covariability among variables into consideration. To further explore the number of genetically homogeneous groups $(K)$ and overall structuring in the dataset, we ran genetic cluster algorithms in STRUCTURE v2.3.4 (Pritchard et al. 2000; Falush et al. 2003, 2007; Hubisz et al. 2009). In the initial analysis, the admixture and correlated allele frequencies models were applied with 50,000 runs as burn-in followed by 150,000 runs. The analysis was run 10 times for each $K$ from 1 to 15 . The probability of obtaining the genotype data $\mathrm{X}$ given $K($ Mean $\operatorname{LnP}(K))$ increased with the number of $K$ s, however, the increase was only marginal from $K=10$ (not shown). Using the $\Delta K$ statistics of Evanno et al. (2005), the most likely number of groups from the preliminary run was 2 . However, using the default setting of $\alpha$ may lead to inaccurate estimates of $K$ and assignments probabilities when population sizes are uneven and under the assumption that populations are descendants of recent ancestral populations (Wang 2017). Thus, we reran the analyses using 50,000 runs as burn-in followed by 150,000 runs, but with adjusted $\alpha$-values based on the initial analyses ( $\alpha=1$ /assumed optimal $K ; \alpha=1 / 10$ and $\alpha=1 / 2$ ), applying the admixture and correlated frequencies models.

The number of likely genetic groups was explored using calculations of Mean $\operatorname{LnP}(K)$ (Pritchard et al. 2000) and $\Delta K$ 
Table 1 Collection information for the 43 investigated sites of Dracocephalum ruyschiana in Norway

\begin{tabular}{|c|c|c|c|c|c|c|}
\hline ID & Site name & Geographical region & Latitude & Longitude & Year & Collector $(\mathrm{s})^{\mathrm{a}}$ \\
\hline $\mathrm{O} 1$ & Malmøya & Oslofjorden & 59,862 & 10,751 & 2014 & $\mathrm{AE}$ \\
\hline $\mathbf{O 2}$ & Ekebergskråningen & Oslofjorden & 59,887 & 10,768 & 2014 & $\mathrm{AE}$ \\
\hline $\mathrm{O} 3$ & Bleikøya & Oslofjorden & 59,888 & 10,735 & 2014 & $\mathrm{AE}$ \\
\hline $\mathrm{O} 4$ & Hovedøya 1 & Oslofjorden & 59,896 & 10,741 & 2014 & $\mathrm{AE}$ \\
\hline 05 & Hovedøya 2 & Oslofjorden & 59,892 & 10,729 & 2014 & $\mathrm{AE}$ \\
\hline O6 & Nakholmen & Oslofjorden & 59,889 & 10,691 & 2013 & $\mathrm{AE}$ \\
\hline $\mathrm{O} 7$ & Trekantenga, Fornebu & Oslofjorden & 59,899 & 10,609 & 2014 & $\mathrm{AE}$ \\
\hline O8 & Klovodden, Ostøya & Oslofjorden & 59,877 & 10,575 & 2014 & $\mathrm{AE}$ \\
\hline O9 & Møllerenga & Oslofjorden & 59,863 & 10,567 & 2014 & OS \\
\hline $\mathrm{O} 10$ & Hesthagebukta & Oslofjorden & 59,861 & 10,570 & 2014 & OS \\
\hline O11 & Lille Ousttangen & Oslofjorden & 59,859 & 10,568 & 2014 & OS \\
\hline $\mathrm{O} 12$ & Nesøya & Oslofjorden & 59,870 & 10,540 & 2014 & $\mathrm{AE}$ \\
\hline $\mathrm{O} 13$ & Brønnøya & Oslofjorden & 59,856 & 10,541 & 2014 & $\mathrm{AE}$ \\
\hline 014 & Spireodden & Oslofjorden & 59,831 & 10,497 & 2014 & ME, OS, MKB \\
\hline $\mathrm{T} 15$ & Bjørketangen & Tyrifjorden & 60,065 & 10,268 & 2014 & OS, MKB \\
\hline T16 & Fekjær & Tyrifjorden & 60,068 & 10,278 & 2014 & $\mathrm{AE}$ \\
\hline T17 & Vik & Tyrifjorden & 60,077 & 10,284 & 2014 & $\mathrm{AE}$ \\
\hline T18 & Åserud & Tyrifjorden & 60,123 & 10,305 & 2014 & OS, MKB \\
\hline T19 & Åsa & Tyrifjorden & 60,131 & 10,323 & 2014 & OS, MKB \\
\hline $\mathrm{T} 20$ & Nordby & Tyrifjorden & 60,141 & 10,334 & 2014 & OS, MKB \\
\hline $\mathrm{T} 21$ & Ulltvedt & Tyrifjorden & 60,141 & 10,323 & 2014 & OS, MKB \\
\hline $\mathrm{T} 22$ & Haug & Tyrifjorden & 60,168 & 10,338 & 2014 & $\mathrm{AE}$ \\
\hline $\mathrm{T} 23$ & Bølgen & Tyrifjorden & 60,179 & 10,350 & 2014 & OS, MKB \\
\hline R24 & Aslaksrud & Randsfjorden & 60,263 & 10,488 & 2014 & OS, MKB \\
\hline $\mathbf{R} 25$ & Klingenberg & Randsfjorden & 60,267 & 10,459 & 2014 & OS, MKB \\
\hline $\mathrm{R} 26$ & Narverud & Randsfjorden & 60,322 & 10,519 & 2014 & OS, MKB \\
\hline R27 & Vien Nedre & Randsfjorden & 60,335 & 10,530 & 2012 & OS \\
\hline $\mathbf{R} 28$ & Falang & Randsfjorden & 60,341 & 10,495 & 2014 & OS, MKB \\
\hline R29 & Lyngstad & Randsfjorden & 60,349 & 10,531 & 2014 & OS, MKB \\
\hline R30 & Skjervum & Randsfjorden & 60,370 & 10,576 & 2014 & OS, MKB \\
\hline R31 & Gjefsen & Randsfjorden & 60,384 & 10,543 & 2014 & OS, MKB \\
\hline $\mathbf{R 3 2}$ & Grindaker & Randsfjorden & 60,402 & 10,488 & 2014 & OS, MKB \\
\hline R33 & Nedre Røykenvik & Randsfjorden & 60,430 & 10,480 & 2014 & OS, MKB \\
\hline R34 & Øvre Røykenvik & Randsfjorden & 60,432 & 10,487 & 2014 & OS, MKB \\
\hline $\mathrm{R} 35$ & Eggelinna & Randsfjorden & 60,433 & 10,499 & 2012 & OS \\
\hline V36 & Thomle & Valdres & 60,851 & 9990 & 2012 & OS \\
\hline V37 & Øygard & Valdres & 61,015 & 9105 & 2012 & OS \\
\hline V38 & Ringerud & Valdres & 61,071 & 9031 & 2012 & OS \\
\hline G39 & Steberg & Gudbrandsdalen & 61,550 & 10,002 & 2013 & $\mathrm{AE}$ \\
\hline G40 & Sørmo & Gudbrandsdalen & 61,286 & 9986 & 2012 & OS \\
\hline $\mathrm{H} 41$ & Bergseng & Hedmark & 61,038 & 10,488 & 2012 & OS \\
\hline $\mathrm{H} 42$ & Veldre & Hedmark & 60,902 & 10,871 & 2012 & OS \\
\hline $\mathrm{H} 43$ & Solberg & Hedmark & 60,753 & 11,571 & 2013 & $\mathrm{AE}$ \\
\hline
\end{tabular}

Site identification (ID, the letter indicating geographical region), site name, geographical region, latitude and longitude of the sampling site, collection year (Year), and collectors are given in the table. Sites included in the monitoring program (Evju et al. 2016) are marked in bold

${ }^{\mathrm{a}} A E$ A. Endrestøl, $O S$ O. Stabbetorp, $M K B$ M. K. Brandrud, $M E$ M. Evju
(Evanno et al. 2005) in Structure Harvester (Earl and vonHoldt 2012). To compare Structure results at multiple values of $K$, we aligned and visualized bar plots using the Clumpak (Cluster Markov Packager across K) web server (Kopelman et al. 2015). 


\section{Results}

A dataset of 355 individuals collected from 43 sites was genotyped for 96 SNPs. The number of individuals sampled from each site varied between two and 13 (Table 2). Eight sites sampled five or fewer individuals, due to small total population sizes, 11 sites had between six and nine individuals, 23 sites had ten individuals, while one had 13. The level of missing SNP data was $0.003 \%$. Genetic variation is summarized in Table 2, showing only small differences between sites. The total mean expected heterozygosity $\left(H_{\mathrm{E}}\right)$ for all individuals was 0.27 , with the lowest level found in site V37 Øygard $\left(H_{\mathrm{E}}=0.20\right.$, two individuals) followed by site G40 Sørmo $\left(H_{\mathrm{E}}=0.21\right.$, three individuals $)$ and site T17 Vik ( $H_{\mathrm{E}}=0.21$, ten individuals), while site R35 Eggelinna had highest $H_{\mathrm{E}}(0.32$, six individuals). The total mean number of different alleles for all individuals was 1.79, ranging from 1.49 (site V37 Øygard) to 1.94 (site G39 Steberg) among sites. The total mean percentage of polymorphic loci over all individuals was $79 \%$. The lowest percentage of polymorphic loci (56\%) was estimated for site T17 Vik, while the highest (94\%) was found in site G39 Steberg. There were no signs of inbreeding as most inbreeding coefficient values $(F)$ were slightly lower than 0 (Table 2).

The AMOVA results (Table 3) showed that most of the genetic variation was found within sites (87\%), while $8 \%$ and $5 \%$ of variation was found among sites and geographical regions, respectively. The total $F_{\mathrm{ST}}$ value was $0.134(\mathrm{p}<0.001)$, while all values estimated between regions were lower than 0.10 (Table 4). The lowest $F_{\mathrm{ST}}$ value was found between Oslofjorden and Randsfjorden $\left(F_{\mathrm{ST}}=0.027\right)$ and the highest between Valdres and Hedmark $\left(F_{\mathrm{ST}}=0.081\right)$. The Mantel test revealed a positive correlation between genetic distance and geographical distance ( $R=0.56, \mathrm{p}=0.001$, Fig. 2$)$.

The estimated likely number of $K$ was not consistent across analyses, however, the different runs yielded the same results across sites, with only small variations in resolution among genetic clusters. Figure 3 shows the major mode of runs in Structure of $K=2-4$ (10/10 runs) and $K=11$ (9/10 runs) using the admixture and correlated frequencies models and $\alpha=0.1$. The Mean $\operatorname{LnP}(K)$ increased as the number of $K$ increased and had not reached an optimum at $K=15$ (Online Resource 1). The $\Delta K$ estimates indicated that $K=2$ was the most likely number of genetic groups for most analyses (Online Resource 1). A combined interpretation of the results obtained for increasing $K$ values showed a hierarchical resolution of genetically homogeneous groups (cf. Meirmans 2015). Individuals from sites in Oslofjorden and site H43 Solberg clustered together, while the rest of the individuals belonged to another genetic group at $K=2$ (Fig. 3). In the latter group, more individuals were admixed between the two groups than were individuals in the former group. When $K=3$, site T17 Vik splits off in a separate group (Fig. 3). There were no admixed individuals in this site and it stayed homogeneous as $K$ increased. The nearby sites consisted of individuals admixed with the "purple" Vik-cluster and mainly the "blue" genetic cluster, but most of the sites split off to separate genetic groups as $K$ increased (see $K=11$ in Fig. 3). At $K=4$ (Fig. 3), sites R24 Aslaksrud, H41 Bergseng and H43 Solberg separated into a fourth homogeneous group. These sites split into separate groups as $K$ increased (see Fig. 3, $K=11$ ). Other sites also split off in distinct groups as $K$ increased, and there was a slight tendency that the sites in the Oslofjord region separated in two; an eastern group and a western group (see $K=11$ in Fig. 3).

The Structure results were supported by the MULTISPATI-PCA result, showing that individuals from sites in the Oslo region group together, while individuals from sites in Randsfjorden group together (Fig. 4). Furthermore, individuals from Tyrifjorden group together, with site T17 Vik at a distance from the other sites. Site H43 Solberg was intermediate of sites from Oslofjorden and Randsfjorden regions, and forms its own group. This is in accordance with the Structure results for $K=4$ (Fig. 3). The genetic variation observed among sites from Oslofjorden and Randsfjorden is thus covered in the monitoring program; these two regions represent the "blue" and "orange" genetic clusters identified by Structure (Fig. 3).

The admixture of genetic groups within sites recognized by Structure was also evident from the results of the assignment test. The test showed that most individuals originated within their sampled region, but within the regions there seemed to be a higher exchange of individuals between sites (Online Resource 2). In sites with no or low numbers of admixed individuals, such as T17 Vik, R24 Aslaksrud, and H43 Solberg, no individuals were assigned to other sites.

\section{Discussion}

Our results indicate the existence of at least four distinct genetic groups of Dracocephalum ruyschiana in Norway, of which only two groups are covered by the current monitoring program. To better conserve the genetic variation present in Norway, and thus a substantial portion of the European genetic variation, we suggest that the monitoring program should include sites with genetic groups not yet covered and downscale coverage of other sites. 
Table 2 Genetic variation within each of 43 sampling sites in Norway of Dracocephalum ruyschiana

\begin{tabular}{|c|c|c|c|c|c|c|c|}
\hline ID & Site name & \# of individuals & PPL & $N_{\mathrm{A}}$ & $H_{\mathrm{E}}$ & $H_{\mathrm{O}}$ & $F$ \\
\hline $\mathrm{O} 1$ & Malmøya & 9 & 83 & $1.83 \pm 0.04$ & $0.33 \pm 0.02$ & $0.30 \pm 0.02$ & $-0.12 \pm 0.03$ \\
\hline $\mathbf{O 2}$ & Ekebergskråningen & 10 & 85 & $1.85 \pm 0.04$ & $0.32 \pm 0.02$ & $0.28 \pm 0.02$ & $-0.11 \pm 0.03$ \\
\hline $\mathrm{O} 3$ & Bleikøya & 10 & 82 & $1.82 \pm 0.04$ & $0.31 \pm 0.02$ & $0.29 \pm 0.02$ & $-0.08 \pm 0.03$ \\
\hline $\mathrm{O} 4$ & Hovedøya 1 & 5 & 68 & $1.68 \pm 0.05$ & $0.29 \pm 0.03$ & $0.26 \pm 0.02$ & $-0.12 \pm 0.04$ \\
\hline 05 & Hovedøya 2 & 10 & 83 & $1.83 \pm 0.04$ & $0.29 \pm 0.02$ & $0.28 \pm 0.02$ & $-0.05 \pm 0.03$ \\
\hline O6 & Nakholmen & 9 & 85 & $1.85 \pm 0.04$ & $0.30 \pm 0.02$ & $0.27 \pm 0.02$ & $-0.10 \pm 0.03$ \\
\hline O7 & Trekantenga, Fornebu & 13 & 93 & $1.93 \pm 0.03$ & $0.32 \pm 0.02$ & $0.30 \pm 0.02$ & $-0.04 \pm 0.03$ \\
\hline O8 & Klovodden, Ostøya & 10 & 81 & $1.81 \pm 0.04$ & $0.29 \pm 0.02$ & $0.28 \pm 0.02$ & $-0.04 \pm 0.04$ \\
\hline O9 & Møllerenga & 10 & 82 & $1.82 \pm 0.04$ & $0.32 \pm 0.02$ & $0.30 \pm 0.02$ & $-0.07 \pm 0.03$ \\
\hline $\mathrm{O} 10$ & Hesthagebukta & 8 & 79 & $1.79 \pm 0.04$ & $0.28 \pm 0.02$ & $0.27 \pm 0.02$ & $-0.02 \pm 0.04$ \\
\hline O11 & Lille Ousttangen & 10 & 80 & $1.80 \pm 0.04$ & $0.30 \pm 0.02$ & $0.27 \pm 0.02$ & $-0.11 \pm 0.03$ \\
\hline $\mathrm{O} 12$ & Nesøya & 8 & 81 & $1.81 \pm 0.04$ & $0.30 \pm 0.02$ & $0.28 \pm 0.02$ & $-0.07 \pm 0.03$ \\
\hline $\mathrm{O} 13$ & Brønnøya & 10 & 90 & $1.90 \pm 0.03$ & $0.34 \pm 0.02$ & $0.31 \pm 0.02$ & $-0.12 \pm 0.03$ \\
\hline \multirow[t]{2}{*}{014} & Spireodden & 10 & 88 & $1.88 \pm 0.03$ & $0.29 \pm 0.02$ & $0.29 \pm 0.02$ & $-0.02 \pm 0.03$ \\
\hline & Oslo region & 132 & 100 & $2.00 \pm 0.00$ & $0.32 \pm 0.02$ & $0.31 \pm 0.02$ & $0.04 \pm 0.01$ \\
\hline $\mathrm{T} 15$ & Bjørketangen & 10 & 82 & $1.82 \pm 0.04$ & $0.26 \pm 0.02$ & $0.27 \pm 0.02$ & $0.03 \pm 0.03$ \\
\hline $\mathrm{T} 16$ & Fekjær & 10 & 82 & $1.82 \pm 0.04$ & $0.26 \pm 0.02$ & $0.27 \pm 0.02$ & $-0.01 \pm 0.03$ \\
\hline $\mathrm{T} 17$ & Vik & 10 & 56 & $1.56 \pm 0.05$ & $0.25 \pm 0.03$ & $0.21 \pm 0.02$ & $-0.19 \pm 0.03$ \\
\hline $\mathrm{T} 18$ & Åserud & 8 & 69 & $1.69 \pm 0.05$ & $0.28 \pm 0.03$ & $0.24 \pm 0.02$ & $-0.13 \pm 0.03$ \\
\hline $\mathrm{T} 19$ & Åsa & 10 & 84 & $1.84 \pm 0.04$ & $0.30 \pm 0.02$ & $0.28 \pm 0.02$ & $-0.06 \pm 0.03$ \\
\hline $\mathrm{T} 20$ & Nordby & 3 & 59 & $1.59 \pm 0.05$ & $0.33 \pm 0.03$ & $0.23 \pm 0.02$ & $-0.38 \pm 0.03$ \\
\hline $\mathrm{T} 21$ & Ulltvedt & 9 & 86 & $1.87 \pm 0.04$ & $0.29 \pm 0.02$ & $0.27 \pm 0.02$ & $-0.09 \pm 0.03$ \\
\hline $\mathrm{T} 22$ & Haug & 10 & 86 & $1.87 \pm 0.04$ & $0.32 \pm 0.02$ & $0.30 \pm 0.02$ & $-0.06 \pm 0.03$ \\
\hline \multirow[t]{2}{*}{$\mathrm{T} 23$} & $\mathrm{~B} ø \operatorname{lgen}$ & 3 & 61 & $1.61 \pm 0.05$ & $0.29 \pm 0.03$ & $0.23 \pm 0.02$ & $-0.25 \pm 0.04$ \\
\hline & Tyrifiorden region & 73 & 98 & $1.98 \pm 0.02$ & $0.30 \pm 0.02$ & $0.28 \pm 0.02$ & $0.06 \pm 0.01$ \\
\hline $\mathbf{R 2 4}$ & Aslaksrud & 10 & 73 & $1.73 \pm 0.05$ & $0.28 \pm 0.02$ & $0.26 \pm 0.02$ & $-0.11 \pm 0.03$ \\
\hline $\mathbf{R 2 5}$ & Klingenberg & 10 & 89 & $1.89 \pm 0.03$ & $0.28 \pm 0.02$ & $0.28 \pm 0.02$ & $0.00 \pm 0.03$ \\
\hline $\mathrm{R} 26$ & Narverud & 10 & 81 & $1.81 \pm 0.04$ & $0.28 \pm 0.02$ & $0.28 \pm 0.02$ & $-0.01 \pm 0.03$ \\
\hline $\mathrm{R} 27$ & Vien Nedre & 9 & 90 & $1.90 \pm 0.03$ & $0.31 \pm 0.02$ & $0.28 \pm 0.02$ & $-0.10 \pm 0.03$ \\
\hline $\mathbf{R} 28$ & Falang & 10 & 88 & $1.88 \pm 0.03$ & $0.32 \pm 0.02$ & $0.29 \pm 0.02$ & $-0.10 \pm 0.03$ \\
\hline $\mathrm{R} 29$ & Lyngstad & 10 & 84 & $1.84 \pm 0.04$ & $0.29 \pm 0.02$ & $0.28 \pm 0.02$ & $-0.04 \pm 0.03$ \\
\hline $\mathbf{R 3 0}$ & Skjervum & 10 & 77 & $1.77 \pm 0.04$ & $0.31 \pm 0.03$ & $0.25 \pm 0.02$ & $-0.19 \pm 0.03$ \\
\hline $\mathbf{R} 31$ & Gjefsen & 7 & 79 & $1.79 \pm 0.04$ & $0.28 \pm 0.02$ & $0.26 \pm 0.02$ & $-0.09 \pm 0.03$ \\
\hline $\mathbf{R 3 2}$ & Grindaker & 10 & 83 & $1.83 \pm 0.04$ & $0.29 \pm 0.02$ & $0.26 \pm 0.02$ & $-0.09 \pm 0.03$ \\
\hline $\mathbf{R 3 3}$ & Nedre Røykenvik & 10 & 91 & $1.91 \pm 0.03$ & $0.30 \pm 0.02$ & $0.29 \pm 0.02$ & $-0.04 \pm 0.03$ \\
\hline $\mathbf{R 3 4}$ & Øvre Røykenvik & 6 & 78 & $1.78 \pm 0.04$ & $0.30 \pm 0.03$ & $0.26 \pm 0.02$ & $-0.14 \pm 0.03$ \\
\hline \multirow[t]{2}{*}{ R35 } & Eggelinna & 6 & 93 & $1.93 \pm 0.03$ & $0.33 \pm 0.02$ & $0.32 \pm 0.02$ & $-0.03 \pm 0.04$ \\
\hline & Randsfjorden region & 108 & 100 & $2.00 \pm 0.00$ & $0.31 \pm 0.01$ & $0.30 \pm 0.01$ & $0.06 \pm 0.01$ \\
\hline V36 & Thomle & 6 & 85 & $1.85 \pm 0.04$ & $0.34 \pm 0.02$ & $0.31 \pm 0.02$ & $-0.11 \pm 0.03$ \\
\hline V37 & Øygard & 2 & 49 & $1.49 \pm 0.05$ & $0.32 \pm 0.04$ & $0.20 \pm 0.02$ & $-0.53 \pm 0.03$ \\
\hline \multirow[t]{2}{*}{ V38 } & Ringerud & 4 & 57 & $1.57 \pm 0.05$ & $0.23 \pm 0.03$ & $0.22 \pm 0.02$ & $-0.08 \pm 0.05$ \\
\hline & Valdres region & 12 & 90 & $1.90 \pm 0.03$ & $0.31 \pm 0.02$ & $0.30 \pm 0.02$ & $-0.01 \pm 0.03$ \\
\hline G39 & Steberg & 10 & 94 & $1.94 \pm 0.03$ & $0.34 \pm 0.02$ & $0.31 \pm 0.02$ & $-0.10 \pm 0.03$ \\
\hline \multirow[t]{2}{*}{ G40 } & Sørmo & 3 & 55 & $1.55 \pm 0.05$ & $0.26 \pm 0.03$ & $0.21 \pm 0.02$ & $-0.27 \pm 0.04$ \\
\hline & Gudbrandsdalen region & 13 & 96 & $1.96 \pm 0.02$ & $0.33 \pm 0.02$ & $0.32 \pm 0.02$ & $0.00 \pm 0.03$ \\
\hline $\mathrm{H} 41$ & Bergseng & 5 & 70 & $1.70 \pm 0.05$ & $0.33 \pm 0.03$ & $0.26 \pm 0.02$ & $-0.24 \pm 0.03$ \\
\hline $\mathrm{H} 42$ & Veldre & 2 & 57 & $1.57 \pm 0.05$ & $0.32 \pm 0.03$ & $0.24 \pm 0.02$ & $-0.35 \pm 0.05$ \\
\hline \multirow[t]{3}{*}{$\mathrm{H} 43$} & Solberg & 10 & 79 & $1.80 \pm 0.04$ & $0.26 \pm 0.02$ & $0.25 \pm 0.02$ & $-0.01 \pm 0.03$ \\
\hline & Hedmark region & 17 & 92 & $1.92 \pm 0.03$ & $0.29 \pm 0.02$ & $0.28 \pm 0.02$ & $0.04 \pm 0.03$ \\
\hline & Total mean & 355 & $79 \pm 2$ & $1.79 \pm 0.01$ & $0.30 \pm 0.00$ & $0.27 \pm 0.00$ & $-0.10 \pm 0.01$ \\
\hline
\end{tabular}

The number of individuals sampled per site (\# of individuals), percentage of polymorphic loci (PPL; \%), average number of alleles at each locus $\left(N_{\mathrm{A}} \pm \mathrm{SE}\right)$, expected heterozygosity $\left(H_{\mathrm{E}} \pm \mathrm{SE}\right)$, observed heterozygosity $\left(H_{\mathrm{O}} \pm \mathrm{SE}\right)$ and the fixation index (inbreeding coefficient, $F \pm \mathrm{SE}$ ) are shown in the table. Sites included in the monitoring program (Evju et al. 2016) are marked in bold 
Table 3 Partitioning of genetic variation among 43 sites in Norway of Dracocephalum ruyschiana using analyses of molecular variance (AMOVA)

\begin{tabular}{lrcc}
\hline & df & $\begin{array}{l}\text { Variance } \\
\text { component }\end{array}$ & Variance (\%) \\
\hline Among regions & 5 & 0.86 & 5 \\
Among sites within regions & 37 & 1.33 & 8 \\
Within sites & 667 & 14.10 & 87 \\
Total & 709 & 16.29 & 100 \\
\hline
\end{tabular}

\section{Genetic diversity and structuring}

Genetic variation in Norwegian populations of $D$. ruyschiana was estimated by expected heterozygosity (total $H_{\mathrm{E}}=0.27$ ) and the levels found were relatively similar among populations (ranging from 0.20 to 0.32). Compared with other threatened plants (e.g. Tero et al. 2005; Dostálek et al. 2010; but see Minasiewicz et al. 2018), the genetic variation in the studied $D$. ruyschiana sites seem to be moderate. As different genetic markers have been applied in these studies, the interpretation of genetic variation should be treated cautiously. There was no sign of inbreeding, as the inbreeding coefficient was close to 0 for most sites. Thus, outcrossing seems to be maintained by pollinating insects (Milberg and Bertilsson 1997). Sites with few individuals have high negative inbreeding coefficients, but are not considered as this is likely an artefact of low sample size. Most of the genetic variation was found within sites $(87 \%)$, indicating low differentiation between sites $\left(F_{\mathrm{ST}}=0.134\right)$. This is comparable to what was found in the close relative $D$. austriacum in the Czech and Slovak Republics; high genetic diversity within populations (80\%) and relatively low differentiation among populations both within and between regions (Dostálek et al. 2010).

In $D$. ruyschiana, isolation by distance was observed which may bias the Structure results (see Perez et al. 2018 and references therein). However, the spatial multivariate analysis (MULTISPATI-PCA) takes spatial data into account and the result obtained is very similar to the Structure result. Therefore, we use the two analyses combined to explore the genetic structuring of Norwegian D. ruyschiana. The PCAresult show that sites in the Oslofjorden region, Randsfjorden

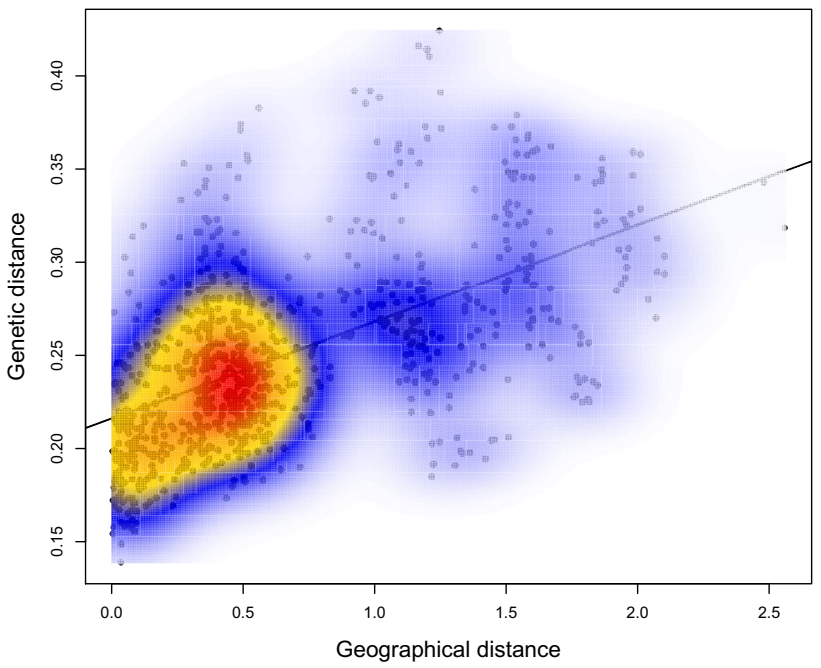

Fig. 2 Relationship between genetic and geographic distance among 43 Dracocephalum ruyschiana sampling sites

region and Tyrifjorden region, form three separate clusters. This finding is supported by the Structure analyses $(K=3)$ showing that sites in the Oslofjorden region belong to the same genetic group ('orange' group, Fig. 3), including site H43 Solberg (Hedmark region) and only a few individuals from other sites. All other sites form a separate group at $K=2$ ('blue' group, Fig. 3), but at $K=3$, a 'purple' group is revealed in Tyrifjorden region. As the number of $K$ increases, more sites splits off in new genetic groups. At $K=4$, H43 Solberg splits off in a 'green' group and also forms its own cluster in the PCA. Hence, genetic variation is geographically structured within the Norwegian distribution of D. ruyschiana.

The Structure results indicate that there is admixture between genetic groups, as two or more genetic groups are presented in single individuals (Fig. 3). Furthermore, individuals from two genetic groups are often found within one site. The assignment test also estimated that several individuals originated from other sites. However, between regions there seems to be limited exchange of individuals. This pattern may reflect gene flow within regions, which is likely as this is an outbreeding species dependent on insects such as Bombus species, for pollination (Milberg and Bertilsson
Table 4 Pairwise $F_{\mathrm{ST}}$ values among six geographic regions in Norway of Dracocephalum ruyschiana

\begin{tabular}{lllllll}
\hline & Oslofjorden & Tyrifjorden & Randsfjorden & Valdres & Gudbrandsdalen & Hedmark \\
\hline Oslofjorden & & & & & & \\
Tyrifjorden & 0.044 & & & & & \\
Randsfjorden & 0.027 & 0.029 & & & & \\
Valdres & 0.059 & 0.053 & 0.034 & & & \\
Gudbrandsdalen & 0.058 & 0.053 & 0.038 & 0.050 & \\
Hedmark & 0.049 & 0.070 & 0.045 & 0.081 & 0.077 & \\
\hline
\end{tabular}



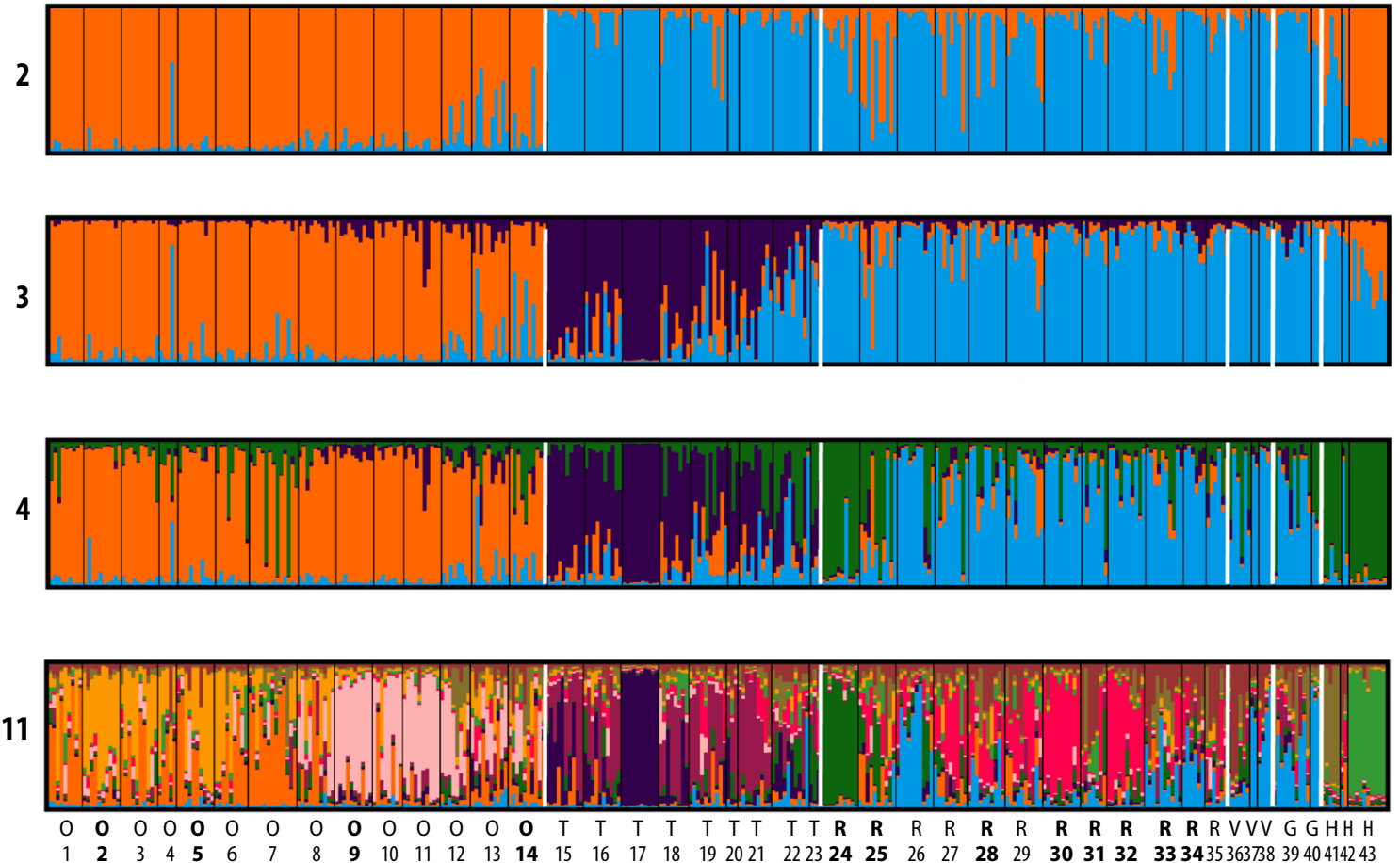

Fig. 3 Genetic structuring in Dracocephalum ruyschiana was investigated using Structure 2.3.4. The barplots show how 355 individuals from 43 sites using 96 SNPs were assigned to different genetic groups $(K)$, when $\mathrm{K}=2,3,4$, and 11 (indicated to the left of the barplots), using admixture and correlated frequencies models and $\alpha=0.1$. For $K=2-4$, the barplots summarize $10 / 10$ runs, while for $K=10$ the

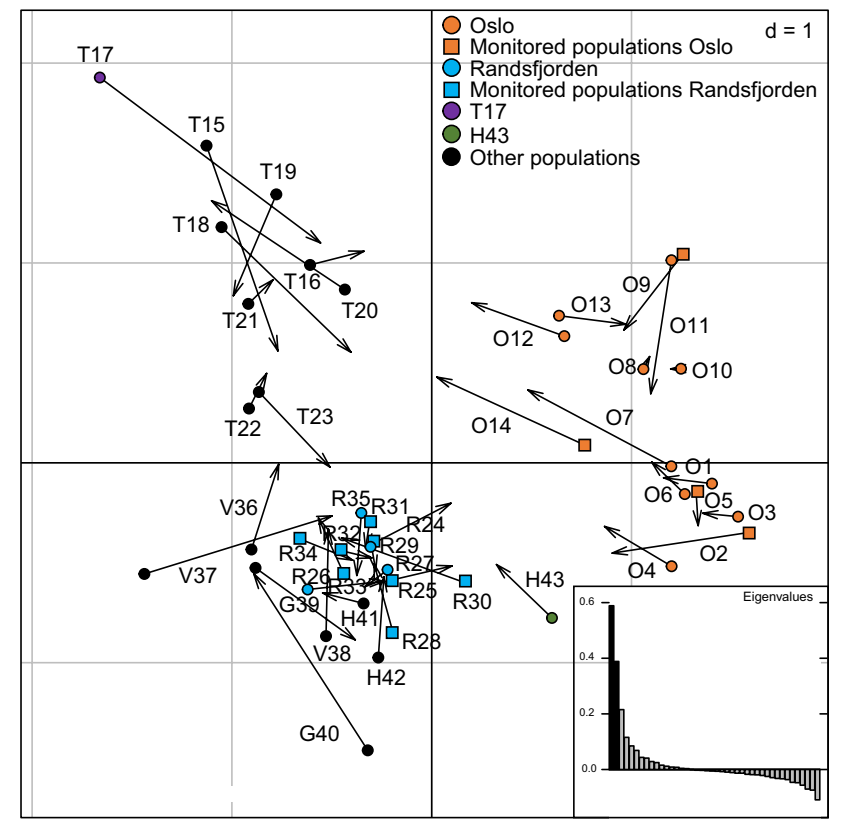

Fig. 4 The PCA shows a spatial multivariate analysis of Dracocephalum ruyschiana. The boxes each represent one site and the site ID follow Table 1 and Fig. 3. Short arrows reveal a local spatial similarity, while a long arrows reveal a spatial discrepancy. The colours indicate the genetic group identified by Structure at $\mathrm{K}=4$ major mode 9/10 runs are shown. The site ID follows Table 1 and Fig. 1 and the assigned geographical regions are indicated by the letter in the ID (O-Oslofjorden, T-Tyrifjorden, R-Randsfjorden, V-Valdres, G-Gudbrandsdalen, H-Hedmark). Sites are separated by black lines, while regions are separated by white lines. The sites that are currently included in demographic monitoring are marked in bold

1997), but over larger distances pollen dispersal becomes more limited. Moreover, the large seeds are not adapted to long distance dispersal (Dostálek et al. 2010). This could explain the observed isolation by distance. However, $F_{\mathrm{ST}^{-}}$ values between regions are very low and might reflect a historically larger meta-population. Land-use change and degradation have lately led to a more fragmented distribution of D. ruyschiana habitat (Evju et al. 2014), with an assessed $30-50 \%$ reduction in population size (Henriksen and Hilmo 2015). If the current distribution range of D. ruyschiana becomes even more fragmentated, a population decline can be expected, potentially leading to a decline in genetic variation and increased genetic isolation (Rubidge et al. 2012). A combination of isolated populations and decreasing numbers of pollinators (Hallmann et al. 2017) could further restrict future outcrossing within and between populations of D. ruyschiana. Reduced outcrossing rates may affect fitness, such as seed production (Milberg and Bertilsson 1997; Castro et al. 2015).

Review studies show a general positive relationship between population size, genetic variation and fitness, meaning larger populations tend to have higher levels of genetic variation and higher fitness (Leimu et al. 2006). Indeed, higher seed production was found in larger, and more 
genetically diverse populations of $D$. austriacum, suggesting that genetic diversity might directly affect plant fitness and populations within this genus (Dostálek et al. 2010, but see Plenk et al. 2019). This finding could also be expected for the close relative D. ruyschiana, though further studies will be necessary to confirm this.

\section{Implications for conservation in Norway}

Mimura et al. (2017) highlight the importance of conserving genetic variation and suggest monitoring of intraspecific genetic variation at global, regional, and local scales. Dracocephalum ruyschiana is threatened both at regional scales (for example Henriksen and Hilmo 2015) and continental scales (Europe; Bern Convention list I). This is the first genetic study of the species, and the first aimed at guiding monitoring and conservation plans. To prioritize among populations in conservation genetics, the delimitation of management units (MUs), defined as populations with different allele frequencies, has been suggested as a suitable conservation approach (Moritz 1994). Based on an interpretation of genetic structure and diversity in Norwegian populations and regions of $D$. ruyschiana, we presently recognize at least four management units corresponding to the groups recognized at $K=4$ ("orange", "blue", "purple", and "green") by Structure (Fig. 3). The Structure result showed that as the number of $K$ increases, more sites seem to split off in separate genetic groups. Nevertheless, the four groups cover all regions and genetic extremes (Fig. 4) studied so far. However, spatial genetic structuring may also be present even at a local scale (Minasiewicz et al. 2018; Tero et al. 2005) and regions such as the valleys stretching north-westwards, represented by few sites and/or individuals, should be further explored for undetected genetic variation in $D$. ruyschiana.

Current demographic monitoring of D. ruyschiana is concentrated on sites in the regions Oslofjorden and Randsfjorden, which together cover the two main genetic groups recognized ("orange" and "blue", respectively). The southernmost sites in Tyriforden seem to be the most genetically distinct sites in this region, with site T17 Vik being the most distinctive (Fig. 4); however, none of these sites are covered by ongoing monitoring. Hence, as a minimum, site T17 Vik should be included in the current monitoring program. Sites from the Hedmark region are also distinct in the analyses, and inclusion of site H43 Solberg in the monitoring program would increase the coverage of genetic variation monitored in Norway. At the same time, monitoring is unduly intense in some areas and some of the sites could be excluded based on genetic similarities, especially from Randsfjorden (Fig. 4). Criteria for exclusion should be based on representativity of habitat types and population states.
The SNP markers used were developed to guide monitoring of genetic variation within Norway and are based on individuals collected throughout the Norwegian distribution (Kleven et al. 2019). If genetic monitoring of the species is implemented in Norway, the markers are well suited for the purpose, as they can easily be applied to additional sites and/or used to monitor the species through time as the results are reproduceable. However, applying other genomic tools could likely aid in identifying locally adaptive genetic variation, revealing other management units (Funk et al. 2012). Genetic analyses of D. austriacum using AFLP markers, demonstrated that neutral and adaptive genetic variation was not correlated (Bonin et al. 2007). Thus, considering both neutral and adaptive genetic variation may be necessary to best conserve the evolutionary potential of a species (Razgour et al. 2018; Mable 2019). Furthermore, increasing our understanding of genetic structure and adaptive variation in D. ruyschiana on both regional and global scales, requires the application of modern genomic tools as well as phylogeographic analyses on a global dataset.

In 2009, Norway updated its laws on management of biodiversity (The Biodiversity Act (Naturmangfoldloven 2009)). The new act aims to give the authorities the possibility to halt the loss of biodiversity, including genetic diversity, through protection and sustainable use of natural resources. Dracocephalum ruyschiana is one species protected by this law. However, studies show a positive correlation between human population density and the loss of rare species (Thompson and Jones 1999), and as D. ruyschiana's core distribution overlaps with the most densely populated areas of Norway, the species is still under pressure of habitat loss and fragmentation (Evju et al. 2014). Loss of populations may have negative consequences for future communities and ecosystems (Des Roches et al. 2018). Therefore, active measures must be applied to prevent further fragmentation and loss of populations of D. ruyschiana. To better protect the species from becoming locally extinct and conserve its evolutionary potential throughout its distribution range, ecologists, geneticists, and conservation managers should work together to develop an integrated, interdisciplinary framework to better inform monitoring programs and conservation actions (Flanagan et al. 2017; Razgour et al. 2018).

Acknowledgements Open Access funding provided by Norwegian institute for nature research. This study was carried out under the project "Management of biodiversity and ecosystem services in spatially structured landscapes" (funded by the Norwegian Research Council, Grant 208434/F40). Permits to sample leaves were approved by the Norwegian Environment Agency (Permit Numbers: 2012 2009/3206 NAK-NK-STB, 2013 2013/3149 NAK-NK-STB and 2014/4159). Thanks to NINA Genlab for assistance in the lab, Benno Dillinger and Kari Sivertsen for helping with figures, and Jesamine Bartlett for 
proofreading the article. We are grateful to two anonymous referees for valuable comments on a previous version of this manuscript.

Open Access This article is licensed under a Creative Commons Attribution 4.0 International License, which permits use, sharing, adaptation, distribution and reproduction in any medium or format, as long as you give appropriate credit to the original author(s) and the source, provide a link to the Creative Commons licence, and indicate if changes were made. The images or other third party material in this article are included in the article's Creative Commons licence, unless indicated otherwise in a credit line to the material. If material is not included in the article's Creative Commons licence and your intended use is not permitted by statutory regulation or exceeds the permitted use, you will need to obtain permission directly from the copyright holder. To view a copy of this licence, visit http://creativecommons.org/licenses/by/4.0/.

\section{References}

Aguilar R, Quesada M, Ashworth L, Herrerias-Diego Y, Lobo J (2008) Genetic consequences of habitat fragmentation in plant populations: susceptible signals in plant traits and methodological approaches. Mol Ecol 17:5177-5188

Allen AM, Hiscock SJ (2008) Evolution and phylogeny of self-incompatibility systems in Angiosperms. In: Franklin-Tong VE (ed) Self-incompatibility in flowering plants. Springer, Berlin, pp 73-102

Barrett RDH, Schluter D (2008) Adaptation from standing genetic variation. Trends Ecol Evol 23:38-44

Birkeland S, Skjetne IEB, Brysting AK, Elven R, Alsos IG (2017) Living on the edge: conservation genetics of seven thermophilous plant species in a high Arctic archipelago. AoB Plants 9:plx001. https://doi.org/10.1093/aobpla/plx001

Bivand R, Altman M, Anselin L, Assuncao R, Berke O, Bernat GA, Müller W (2008) spdep: spatial dependence: weighting schemes, statistics and models. R package version 0.4-17

Bonin A, Nicole F, Pompanon F, Miaud C, Taberlet P (2007) Population adaptive index: a new method to help measure intraspecific genetic diversity and prioritize populations for conservation. Conserv Biol 21:697-708

Bowen BW (1999) Preserving genes, species, or ecosystems? Healing the fractured foundations of conservation policy. Mol Ecol 8:S5-S10

Bruford MW, Davies N, Dulloo ME, Faith DP, Walters M (2017) Monitoring changes in genetic diversity. In: Walters M, Scholes $\mathrm{R}$ (eds) The GEO handbook on biodiversity observation networks. Springer, Cham

Castro S, Dostálek T, van der Meer S, Ostermeijer G, Münzbergová Z (2015) Does pollen limitation affect population growth of the endangered Dracocephalum austriacum L.? Popul Ecol $57: 105-116$

Ceballos G, Ehrlich PR, Barnosky AD, García A, Pringle RM, Palmer TM (2015) Accelerated modern human-induced species losses: entering the sixth mass extinction. Sci Adv 1:e1400253

Crutsinger GM, Collins MD, Fordyce JA, Gompert Z, Nice CC, Sanders NJ (2006) Plant Genotypic diversity predicts community structure and governs an ecosystem process. Science 313:966

Des Roches S, Post DM, Turley NE, Bailey JK, Hendry AP, Kinnison MT, Schweitzer JA, Palkovacs EP (2018) The ecological importance of intraspecific variation. Nat Ecol Evol 2:57-64

Dostálek T, Münzbergová Z, Plačková I (2010) Genetic diversity and its effect on fitness in an endangered plant species, Dracocephalum austriacum L. Conserv Genet 11:773-783
Dray S, Dufour A-B (2007) The ade4 package: implementing the duality diagram for ecologists. J Stat Softw 22:1-20

Dray S, Said S, Debias F (2008) Spatial ordination of vegetation data using a generalization of Wartenberg's multivariate spatial correlation. J Veg Sci 19:45-56

Earl DA, vonHoldt BM (2012) Structure Harvester: a website and program for visualizing Structure output and implementing the Evanno method. Conserv Genet Resour 4:359-361

Evanno G, Regnaut S, Goudet J (2005) Detecting the number of clusters of individuals using the software STRUCTURE: a simulation study. Mol Ecol 14:2611-2620

Evju M, Blumentrath S, Skarpaas O, Stabbetorp OE, Sverdrup-Thygeson A (2014) Plant species occurrence in a fragmented grassland landscape: the importance of species traits. Biodivers Conserv 3:547-561

Evju M, Skarpaas O, Stabbetorp OE (2016) Dragehode Dracocephalum ruyschiana. Forslag til overvåkingsopplegg. NINA Kortrapport, $\mathrm{p} 30$

Excoffier L, Lischer HEL (2010) Arlequin suite ver 3.5: a new series of programs to perform population genetics analyses under Linux and Windows. Mol Ecol Resour 10:564-567

Fægri K, Danielsen A (1996) Maps of distribution of Norwegian vascular plants. III. The southeastern element. Fagbokforlaget, Bergen

Falush D, Stephens M, Pritchard JK (2003) Inference of population structure using multilocus genotype data: linked loci and correlated allele frequencies. Genetics 164:1567-1587

Falush D, Stephens M, Pritchard HW (2007) Inference of population structure using multilocus genotype data: dominant markers and null alleles. Mol Ecol Notes 1:574-578

Flanagan SP, Forester BR, Latch EK, Aitken SN, Hoban S (2017) Guidelines for planning genomic assessment and monitoring of locally adaptive variation to inform species conservation. Evol Appl 11:1035-1052

Funk WC, McKay JK, Hohenlohe PA, Allendorf FW (2012) Harnessing genomics for delineating conservation units. Trends Ecol Evol 27:489-496

García-Ramos G, Kirkpatrick M (1997) Genetic models of adaptation and gene flow in peripheral populations. Evolution 51:21-28

Gärdenfors U (ed) (2005) The 2005 Red List of Swedish species. ArtDatabanken, SLU, Uppsala

Hallmann CA, Sorg M, Jongejans E, Siepel H, Hofland N, Schwan H, Stenmans W, Müller A, Sumser H, Hörren T, Goulson D, de Kroon H (2017) More than 75 percent decline over 27 years in total flying insect biomass in protected areas. PLoS ONE 12:e0185809

Henriksen S, Hilmo O (2015) Norsk rødliste for arter 2015. Artsdatabanken, Norge

Hubisz MJ, Falush D, Stephens M, Pritchard JK (2009) Inferring weak population structure with the assistance of sample group information. Mol Ecol Resour 9:1322-1332

Hughes AR, Inouye BD, Johnson MTJ, Underwood N, Vellend M (2008) Ecological consequences of genetic diversity. Ecol Lett 11:609-623

IPBES (2019) In: Brondizio ES, Settele J, Díaz S, Ngo HT (eds) Global assessment report on biodiversity and ecosystem services of the Intergovernmental Science-Policy Platform on Biodiversity and Ecosystem Services. IPBES Secretariat, Bonn

Käsermann C, Moser DM (1999) Datasheets for conservation. Flowering plants and ferns (original title in French: Fiches Pratiques pour la Conservation. Plantes à Fleurs et Fougères.). Ed. OFEFP, Berne

Keller LF, Waller DM (2002) Inbreeding effects in wild populations. Trends Ecol Evol 17:230-241

Király G (ed) (2007) Vörös Lista. A magyarországi edényes flóra veszélyeztetett fajai. (Red list of the vascular flora of Hungary). Saját kiadás, Sopron 
Kleven O, Endrestøl A, Evju M, Stabbetorp OE, Westergaard KB (2019) SNP discovery in the northern dragonhead Dracocephalum ruyschiana. Conserv Genet Resour 11:431-435

Kopelman NM, Mayzel J, Jakobsson M, Rosenberg NA, Mayrose I (2015) Clumpak: a program for identifying clustering modes and packaging population structure inferences across K. Mol Ecol Resour 15:1179-1191

Laikre L (2010) Genetic diversity is overlooked in international conservation policy implementation. Conserv Genet 11:349-354

Laikre L, Allendorf FW, Aroner LC, Baker CS, Gregovich DP, Hansen MM, Jackson JA, Kendall KC, McKelvey K, Neel MC, Olivieri I, Ryman N, Schwartz MK, Bull RS, Stetz JB, Tallmon DA, Taylor BL, Vojta CD, Waller DM, Waples RS (2010) Neglect of genetic diversity in implementation of the convention on biological diversity. Conserv Biol 24:86-88

Lazarević P, Lazarević M, Krivošej Z, Stevanović V (2009) On the distribution of Dracocephalum ruyschiana (Lamiaceae) in the Balkan Peninsula. Phytol Balc 15:175-179

Leimu R, Mutikainen P, Koricheva J, Fischer M (2006) How general are positive relationships between plant population size, fitness and genetic variation? J Ecol 94:942-952

Lid J, Lid D (2005) In: Elven R (ed) Norsk Flora. 7 edn. Det Norske Samlaget, Oslo

Lovdata (2011) Forskrift om dragehode (Dracocephalum ruyschiana) som prioritert art. https://lovdata.no/dokument/SF/forskrift/201105-20-517?q=prioritert\%20art. 29 Jan 2019

Mable BK (2019) Conservation of adaptive potential and functional diversity: integrating old and new approaches. Conserv Genet $1: 89-100$

Meirmans PC (2015) Seven common mistakes in population genetics and how ro avoid them. Mol Ecol 24:3223-3231

Milberg P, Bertilsson A (1997) What determines seed set in Dracocephalum ryuschiana $\mathrm{L}$. an endangered grassland plant. Flora 192:361-367

Mimura M, Yahara T, Faith DP, Vázquez-Domínguez A, Colautti R, Araki H, Javadi F, Núñez-Farfán J, Mori AS, Zhou S, Hollingsworth PM, Neaves LE, Fukani Y, Smith GF, Yo-Ichiro S, Tachida H, Hendry AP (2017) Understanding and monitoring the consequences of human impacts on intraspecific variation. Evol Appl 10:121-139

Minasiewicz J, Znaniecka JM, Górniak M, Kawiński A (2018) Spatial genetic structuring of an endangered orchid Cyripedium calceolus (Orchidaceae) at a regional scale: limited gene flow in a fragmented landscape. Conserv Genet 19:1449-1460

Moritz C (1994) Defining 'Evolutionary Significant Units' for conservation. Trends Ecol Evol 9:373-375

Naturmangfoldloven (2009) Lov om forvaltning av naturens mangfold (LOV-2009-06-19-100) https://lovdata.no/dokument/NL/ lov/2009-06-19-100. Accessed 29 Jan 2019

Norwegian Directorate for Nature Management (2010) Action plan for the northern dragonhead Dracocephalum ruyschiana and dragonhead sap beetle Meligethes norvegicus. Trondheim, DN-Report, 2010-5

Osborne M, Sharp A, Monzingo J, Propst DL, Turner TFJCG (2012) Genetic analysis suggests high conservation value of peripheral populations of Chihuahau chub (Gila nigrescens). Conserv Genet 13:1317-1328

Owens SJ, Ubera-Jiménez JL (1992) Breeding systems in Labiatae. In: Harley RM, Rynolds T (eds) Advances in Labiatae science. The Royal Botanical Gardens Kew, Richmond

Peakall R, Smouse PE (2006) GENALEX 6: genetic analysis in Excel. Population genetic software for teaching and research. Mol Ecol Notes 6:288-295

Peakall R, Smouse PE (2012) GenAlEx 6.5: genetic analysis in Excel. Population genetic software for teaching and research—an update. Bioinformatics 28:2537-2539

Perez MF, Franco FF, Bombonato JR, Bonatelli IAS, Khan G, Romeiro-Brito M, Fegies AC, Ribeiro PM, Silva GAR, Moraes
EM (2018) Assessing population structure in the face of isolation by distance: are we neglecting the problem? Divers Distrib 24:1883-1889

Plenk K, Bardy K, Höhn M, Kropf M (2019) Long-term survival and successful conservation? Low genetic diversity but no evidence for reduced reproductive success at the north-westernmost range edge og Poa badensis (Poaceae) in Central Europe. Biodivers Conserv 28:1245-1265

Pritchard JK, Stephens M, Donnelly P (2000) Inference of population structure using multilocus genotype data. Genetics 155:945-959

Razgour O, Juste J, Ibáñez C, Kiefer A, Rebelo H, Puechmaille SJ, Arlettaz R, Burke T, Dawson DA, Beaumont M, Jones G (2013) The shaping of genetic variation in edge-of-range populations under past and future climate change. Ecol Lett 16:1258-1266

Razgour O, Taggart JB, Manel S, Juste J, Ibáñez C, Rebelo H, Alberdi A, Jones G, Park K (2018) An integrated framework to identify wildlife populations under threat from climate change. Mol Ecol 18:18-31

Reusch TBH, Ehlers A, Hämmerli A, Worm B (2005) Ecosystem recovery after climatic extremes enhanced by genotypic diversity. PNAS 102:2826-2831

Rivers MC, Brummitt NA, Nic Lughadha E, Meagher TR (2014) Do species conservation assessments capture genetic diversity? Glob Ecol Conserv 2:81-87

RStudio Team (2015) RStudio: integrated development for R. RStudio, Inc., Boston, MA. http://www.rstudio.com.

Rubidge EM, Patton JL, Lim M, Cole Burton A, Brashares JS, Moritz C (2012) Climate-induces range contraction drives genetic erosion in an alpine mammal. Nat Clim Change 2:285-288

GBIF Secretariat (2017). GBIF Backbone Taxonomy. Dracocephalum ruyschiana L. Checklist dataset. https://doi.org/10.15468/39ome i. Accessed via GBIF.org on 10 Aug 2019

Solstad H, Elven R, Mjelde M, Pedersen O, Alsos IG, Stabbetorp O, Gaarder G (2015) Karplanter. Pteridophyta, Pinophyta, Magnoliophyta. In: Henriksen S, Hilmo O (eds) Norsk rødliste for arter 2015. Artsdatabanken, Norge

Tero N, Aspi J, Siikamäki P, Jäkäläniemi A (2005) Local genetic population structure in an endagnered plant species, Silene tatarica (Caryophyllaceae). Heredity 94:478-487

Thompson K, Jones A (1999) Human population density and prediction of local plant extinction in Britain. Conserv Biol 13:185-189

Wagner V, Treiber J, Danihelka J, Ruprecht E, Wesche K, Hensen I (2012) Declining genetic diversity and increasing genetic isolation toward the range periphery of stipa pennata, a eurasian feather grass. Int J Plant Sci 173:802-811.

Wang J (2017) The computer program structure for assigning individuals to populations: easy to use but easier to misuse. Mol Ecol Resour 17:981-990

Westergaard KB, Arnesen G, Alsos IG (2011a) En finnmarkings levevilkår: den sterkt truede masimjelten Oxytropis deflexa ssp. norvegica. Ecofact rapport, $\mathrm{p} 25$

Westergaard KB, Arnesen G, Alsos IG (2011b) Genetiske undersøkelser av den kritisk trua polarflokken Polemonium boreale ved Bugøynes, Finnmark. Ecofact report, p 15

Westergaard KB, Zemp N, Bruederle LP, Stenøien HK, Widmer A, Fior S (2019) Population genomic evidence for plant glacial survival in Scandinavia. Mol Ecol 28:818-832

Witkowski ZJ, Król W, Solarz W (eds) (2003) Carpathian List Of Endangered Species. WWF and Institute of Nature Conservation, Polish Academy of Sciences, Vienna-Krakow

Publisher's Note Springer Nature remains neutral with regard to jurisdictional claims in published maps and institutional affiliations. 